\title{
STABILIZATION OF UNUSUAL SUBSTRATE COORDINATION MODES IN DINUCLEAR MACROCYCLIC COMPLEXES
}

\author{
Vasile Lozan \\ Institute of Chemistry of ASM, 3 Academiei str., Chisinau, MD 2028, R. Moldova \\ e-mail:vasilelozan@gmail.com
}

\begin{abstract}
The steric protection offered by the macrobinucleating hexaaza-di tiophenolate ligand (L) allows for the preparation of the first stable dinuclear nickel(II) borohydride bridged complex, which reacts rapidly with elemental sulphur producing a tetranuclear nickel(II) complex $\left[\left\{\left(\mathrm{L} \mathrm{Ni}_{2}\right\}_{2}\left(\mu-\mathrm{S}_{6}\right)\right]^{2+}\right.$ bearing a helical $\mu_{4}$-hexasulfide ligand. The $\left[(\mathrm{L}) \mathrm{Co}_{2}{ }_{2}\right]^{2+}$ fragment have been able to trap a monomethyl orthomolybdate in the binding pocket. Unusual coordination modes of substrate in dinuclear macrocyclic compounds was demonstrated.
\end{abstract}

Keywords: coordination chemistry, borohydride, hexasulphide, molybdate, amino-thiophenolate ligands.

\section{Introduction}

The study of the coordination chemistry of classical coordination compounds with deep binding cavities is an active research area [1,2]. Motivations in this area are diverse and include molecular recognition of neutral or charged guest molecules, [3,4] stabilization of unusual substrate coordination modes, isolation of reactive species, [5] promotion of reactions within their interiors, [6-11] and construction of more effective enzyme active site mimetics, [12] to name but a few. Various types of supporting ligands for such complexes have been developed. Most of them represent mononucleating systems derived from cyclodextrines, [6] calixarenes [13], Schiff-base calixarene hybrids, and some highly functionalized tripod ligands [14-18]. Much less is known of ligand systems that encapsulate polynuclear core structures, and the chemistry of such systems is not well explored [19-21]. The coordination chemistry of binucleating hexaazadithiophenolate macrocycles has been reviewed [22-24].

The ligand $\mathrm{H}_{2} \mathrm{~L}$ is effective dinucleating ligand towards various divalent metal ions. Complexes of composition $\left[(\mathrm{L}) \mathrm{M}_{2}^{\mathrm{II}}\left(\mu-\mathrm{L}^{\prime}\right)\right]^{+}(\mathrm{M}=\mathrm{Mn}, \mathrm{Fe}, \mathrm{Co}, \mathrm{Ni}, \mathrm{Zn}, \mathrm{Cd})$ bearing $\mathrm{Cl}^{-}$and $\mathrm{OAc}^{-}$coligands (L') (Fig. 1) can be readily obtained by the treatment of the free ligand $\mathrm{H}_{2} \mathrm{~L}$ with two equivalents of the corresponding metal(II) dihalogenides $\left(\mathrm{MCl}_{2}\right)$ or acetates $\left(\mathrm{M}(\mathrm{OAc})_{2}\right)$ in methanolic solution in the presence of a base [24]. Interestingly, the macrocycles can adopt two different conformations A and B (Fig. 1), which are reminiscent of the "partial cone" and "cone" conformations of the calixarenes. The complexes of the $3 \mathrm{~d}$ elements of the type A conformation is only seen for small monoatomic bridging ligands such as $\mathrm{L}^{\prime}=\mathrm{OH}^{-}$and $\mathrm{Cl}^{-}$. For large coligands (such as $\mathrm{N}_{3}^{-}$) or a multiatom bridging ligand (such as $\mathrm{OAc}^{-}$) the bowl-shaped conformation $\mathrm{B}$ is assumed, the driving force being the more regular octahedral coordination environments about the $\mathrm{M}^{\mathrm{II}}$ ions.
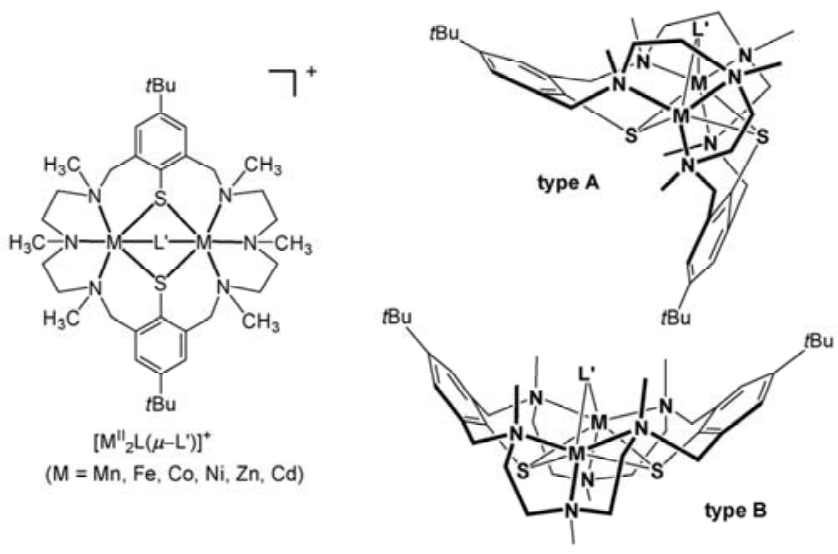

Fig. 1. Cationic $\left[\mathrm{M}^{\mathrm{II}}{ }_{2}(\mathrm{~L})\left(\mu-\mathrm{L}^{\prime}\right)\right]^{+}$complexes supported by the ligands $(\mathrm{L})^{2-}$ and schematic representation of their structures $\left(L^{\prime}=\right.$ coligand)

These complexes have a rich coordination chemistry since the $\left[(\mathrm{L}) \mathrm{M}_{2}\right]^{2+}$ fragments are able to coordinate a large variety of coligands such as $\mathrm{Cl}^{-}$[26 ], $\mathrm{OH}^{-}$[27], $\mathrm{NO}_{2}^{-}, \mathrm{NO}_{3}^{-}, \mathrm{N}_{3}^{-}$[28], and various carboxylates [29-33]. Some of the complexes feature unusual ligand coordination modes. The azide complex $\left[(\mathrm{L}) \mathrm{Ni}_{2}\left(\mu-\mathrm{N}_{3}\right)\right]^{+}$is a representative example. The planarity of the $\mathrm{Ni}-\mathrm{N}_{3}-\mathrm{Ni}$ assembly (torsional angle $\tau=0^{\circ}$ ) together with the remarkably obtuse $\mathrm{Ni}-\mathrm{N}-\mathrm{N}$ angles at 109.9(2) ${ }^{\circ}$ has never been observed before for $\mathrm{M}-\mu_{1,3}-\mathrm{N}_{3}-\mathrm{M}$ linkages [34-36]. The presence of this distinct binding 
mode can be traced to the complementary size and form of the binding pocket of the $\left[(\mathrm{L}) \mathrm{Ni}_{2}\right]^{2+}$ complex. The hydrazine complex $\left[(\mathrm{L}) \mathrm{Ni}_{2}\left(\mu-\mathrm{N}_{2} \mathrm{H}_{4}\right)\right]^{2+}$ is an example for a complex that features an unusual conformation of a small neutral inorganic molecule. Free hydrazine exists predominantly in the gauche conformation at room temperature (dihedral angle $\tau \sim 100^{\circ}$ ) [37], also most commonly seen in dinuclear hydrazine complexes [38,39]. In $\left[(\mathrm{L}) \mathrm{Ni}_{2}\left(\mu-\mathrm{N}_{2} \mathrm{H}_{4}\right)\right]^{2+}$ the $\mathrm{N}_{2} \mathrm{H}_{4}$ ligand can only adopt the $c i s$ (ecliptic) conformation $\left(\tau=3.7^{\circ}\right)$. To the best of our knowledge, such a coordination mode is without precedence in dinuclear transition metal hydrazine complexes [40-44], albeit it is documented for mononuclear species $[45,46]$. The ecliptic $\mathrm{N}_{2} \mathrm{H}_{4}$ conformation is presumably a consequence of repulsive $\mathrm{NH} \cdots \mathrm{C}_{\text {aryl }}$ van der Waals interactions between the $\mathrm{N}_{2} \mathrm{H}_{4}$ molecule and (L) ${ }^{2-}$.

Table 1 lists the synthesized complexes and their labels. Of these, the complexes 1, 2, 3 and 9 have been reported earlier [26,27,30,47].

Synthesized complexes and their labels ${ }^{[a]}$

Table 1

\begin{tabular}{|l|l|l|}
\hline \multicolumn{2}{|l|}{$\left[(\mathbf{L}) \mathrm{Ni}_{2}\left(\mu-\mathrm{L}^{\prime}\right)\right]^{+}$} & \multicolumn{1}{c|}{$\mathbf{L}^{\prime}$} \\
\hline $1^{\mathrm{b}}$ & {$\left[(\mathrm{L}) \mathrm{Ni}_{2}(\mu-\mathrm{Cl})\right]^{+}$} & Chloride, $\mathrm{Cl}^{-}$ \\
\hline $2^{\mathrm{c}}$ & {$\left[(\mathrm{L}) \mathrm{Ni}_{2}(\mu-\mathrm{OH})\right]^{+}$} & Hydroxide, $\mathrm{OH}^{-}$ \\
\hline $3^{\mathrm{d}}$ & {$\left[(\mathrm{L}) \mathrm{Ni}_{2}\left(\mu-\mathrm{ClO}_{4}\right)\right]^{+}$} & Perclorate, $\mathrm{ClO}_{4}^{-}$ \\
\hline 4 & {$\left[(\mathrm{~L}) \mathrm{Ni}_{2}\left(\mu-\mathrm{BH}_{4}\right)\right]^{+}$} & Borohydride, $\mathrm{BH}_{4}^{-}$ \\
\hline 5 & {$\left[(\mathrm{~L}) \mathrm{Ni}_{2}(\mu-\mathrm{HCOO})\right]^{+}$} & Formiate, $\mathrm{HCOO}^{-}$ \\
\hline 6 & {$\left[(\mathrm{~L}) \mathrm{Ni}_{2}(\mu-\mathrm{SH})\right]^{+}$} & Hydrosulfide, $\mathrm{HS}^{-}$ \\
\hline 7 & {$\left[\left\{(\mathrm{~L}) \mathrm{Ni}_{2}\right\}_{2}\left(\mu-\mathrm{S}_{6}\right)\right]^{2+}$} & Hexasulfide, $\mathrm{S}_{6}^{-}$ \\
\hline 8 & {$\left[(\mathrm{~L}) \mathrm{Ni}_{2}(\mu-\mathrm{SPh})\right]^{2+}$} & Thiophenol, $\mathrm{C}_{6} \mathrm{H}_{5} \mathrm{~S}^{-}$ \\
\hline $9^{\mathrm{e}}$ & {$\left[(\mathrm{L}) \mathrm{Co}_{2}(\mu-\mathrm{Cl})\right]^{+}$} & Chloride, $\mathrm{Cl}^{-}$ \\
\hline 10 & {$\left[(\mathrm{~L}) \mathrm{Co}_{2}\left(\mu-\mathrm{MoO}_{4}\right)\right]^{+}$} & Molybdate, $\mathrm{MoO}_{4}^{2-}$ \\
\hline 11 & {$\left[(\mathrm{~L}) \mathrm{Co}_{2}\left(\mu-\mathrm{MoO}_{3}(\mathrm{OMe})\right)\right]^{+}$} & Methylmolybdate, $\mathrm{MoO}_{3}(\mathrm{OMe})^{-}$ \\
\hline
\end{tabular}

[a] The complexes were isolated as $\mathrm{ClO}_{4}^{-}$or $\mathrm{BPh}_{4}^{-}$salts. [b] Ref. [26].

[c] Ref. [27]. [d] Ref. [47]. [e] Ref. [30].

In the following, selected examples of unusual substrate coordination modes originating from this work will be presented and discussed.

\section{Stabilisation of a bridging borohydride co-ligand in dinickel(II) macrocyclic complex}

The search for dinuclear dithiolato-bridged complexes which model key features of the active site of hydrogenase enzymes is an active research area [48,49]. Two main strategies exist to access such compounds. One involves the addition of an electrophilic metal-carbonyl fragment to a nucleophilic metal complex with cis-oriented thiolate functions [50]. The resulting $\left[\mathrm{NiFeS}_{2}\right]$, or $\left[\mathrm{Fe}_{2} \mathrm{~S}_{2}\right]$, assemblies are co-ligated with $\mathrm{CO}$ and $\mathrm{CN}^{-}$and represent good structural analogues of the proposed active site structures, as demonstrated recently by a number of research groups [51-54]. In the other strategy, macrocyclic dinucleating polyaza-dithiolate ligands are used for the cluster assembly [55]. Until now this strategy has only allowed for the production of homodinuclear nickel complexes, and it is unclear at present whether these more classical Werner type coordination compounds will ever be able to bind the biologically relevant co-ligands $\mathrm{CO}, \mathrm{CN}^{-}$and $\mathrm{H}^{-}$. Herein we provide the first evidence for nickel-hydrogen interactions in such compounds. Our study was initiated by the recent discovery of Desrochers et al. [56], who demonstrated that the sterically encumbered hydrotris-(3,5-dimethyl-pyrazolyl)borate ligand $\left(\mathrm{Tp}^{*^{-}}\right)$can stabilize a hydrogen-rich nickel environment in $\left[\mathrm{Tp}^{*} \mathrm{Ni}^{\mathrm{II}}\left(\mu_{1,3}-\mathrm{BH}_{4}\right)\right]$. In order to test whether similar dinickel(II) complexes with a bridging borohydride coligand are supported by the dinucleating hexaaza-dithiophenolate ligand $(\mathrm{L})^{2-}[26]$ an acetonitrile solution of the chloro-bridged complex $\left[(\mathrm{L}) \mathrm{Ni}_{2}{ }_{2}(\mu-\mathrm{Cl})\right] \mathrm{ClO}_{4}\left(\mathbf{1}-\mathrm{ClO}_{4}\right)$ was treated with $\mathrm{n}-\mathrm{Bu}_{4} \mathrm{NBH}_{4}$ under an argon atmosphere at ambient temperature. Unlike [ $\left.\mathrm{Tp}^{*} \mathrm{Ni}^{\mathrm{II}} \mathrm{Cl}\right],[56]$ however, no reaction occurred. In a second approach, the reaction was carried out using the dark green perchlorato-bridged complex $\left[(\mathrm{L}) \mathrm{Ni}_{2}{ }_{2}\left(\mu-\mathrm{ClO}_{4}\right)\right] \mathrm{ClO}_{4}\left(3 \cdot \mathrm{ClO}_{4}\right)$ which was prepared by $\mathrm{Cl}^{-}$abstraction from 1- $\mathrm{ClO}_{4}$ with $\mathrm{Pb}\left(\mathrm{ClO}_{4}\right)_{2}$. This gave a pale-green solution of the desired borohydrido-bridged complex 4, which was isolated as its $\mathrm{BPh}_{4}^{-}$salt in ca. $75 \%$ yield. In the absence of air and protic reagents this compound is stable for weeks, both in the solid state and in solution. This stability is quite remarkable given that nickel(II) complexes of sterically less demanding ligands are readily reduced to nickel boride [57].

IR measurements of solid $4 \cdot \mathrm{BPh}_{4}$ showed intense absorption bands at 2390, 2360, 2153 and $2071 \mathrm{~cm}^{-1}$ indicative of terminal $\mathrm{B}-\mathrm{H}$ and bridging $\mathrm{B}-\mathrm{H} \cdots \mathrm{Ni}$ functions [58]. The $\mathrm{UV}-\mathrm{Vis}$ spectrum recorded in acetonitrile suggested the 
presence of octahedral $\mathrm{Ni}(\mathrm{II})$ ions $\left[\lambda=650\left(\mathrm{v}_{2}\right)\right.$ and $\left.1074 \mathrm{~nm}\left(\mathrm{v}_{1}\right)\right]$ [29]. Final confirmation came from an X-ray crystal structure determination of $4 \cdot \mathrm{BPh}_{4} \cdot 2 \mathrm{MeCN}$ (Fig. 2). As can be seen, the $\mathrm{BH}_{4}^{-}$ion bridges the two $\mathrm{Ni}$ (II) centres in a symmetrical fashion to generate a bioctahedral $\mathrm{N}_{3} \mathrm{Ni}^{\mathrm{II}}(\mu-\mathrm{S})_{2}\left(\mu-\mathrm{BH}_{4}\right) \mathrm{Ni}^{\mathrm{II}} \mathrm{N}_{3}$ core structure that has never been observed before in nickel-thiolate chemistry. There are no interactions between the MeCN of solvent of crystallization and the $\left[(\mathrm{L}) \mathrm{Ni}_{2}{ }_{2}\left(\mu-\mathrm{BH}_{4}\right)\right]^{+}$cations. The average $\mathrm{Ni}-\mathrm{H}$ distance at $1.89(4) \AA$ compares well with that in the mononuclear $\mathrm{NiS}_{4} \mathrm{H}_{2}$ complex [Ni $\left.{ }^{\mathrm{II}}(\mathrm{bmp})_{2}\right]$ (bmp = bis(2-mercapto-1-methyl-imidazolyl)-borate), [59] the only other sulfur-rich $\mathrm{Ni}(\mathrm{II})$ complex with $\mathrm{B}-\mathrm{H} \cdots \mathrm{Ni}$ interactions that has been structurally characterised.

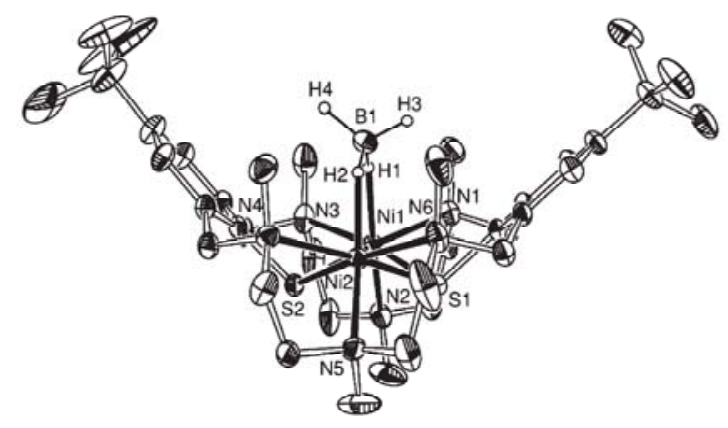

Fig. 2. ORTEP representation of the structure of complex 4 at $50 \%$ probability ellipsoids. Hydrogen atoms, except those of the $\mathrm{BH}_{4}^{-}$coligand, have been omitted for clarity.

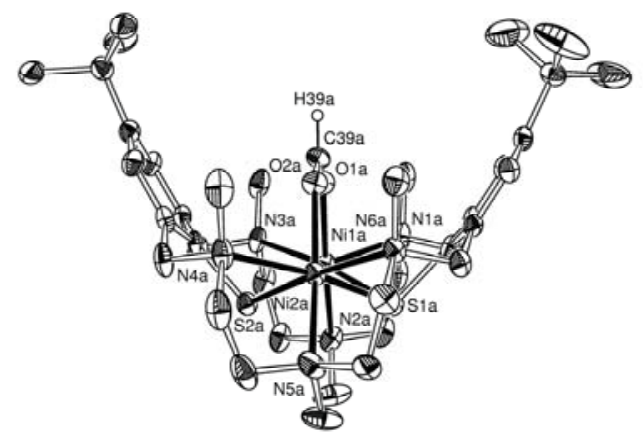

Fig. 3. ORTEP representation of the structure of the formato complex 5 with thermal ellipsoids drawn at the $50 \%$ probability level. Hydrogen atoms, except that of the formato coligand, have been omitted for clarity.

Preliminary results show that 4 reacts with protic reagents $\mathrm{HA}$, such as $\mathrm{HCl}, \mathrm{H}_{2} \mathrm{O}$, or $\mathrm{HCO}_{2} \mathrm{H}$ with liberation of $\mathrm{H}_{2}$ and formation of the respective $\left[(\mathrm{L}) \mathrm{Ni}_{2}{ }_{2}(\mathrm{~A})\right]^{+}$species $\left(\mathrm{A}=\mathrm{Cl}^{-} \mathbf{1}, \mathrm{OH}^{-} \mathbf{2}\right.$ and $\left.\mathrm{HCO}_{2}^{-} \mathbf{5}\right)$. The new complex $\mathbf{5}$ is also readily produced by the reaction of 3 with $\mathrm{CO}_{2}$. IR measurements of $\mathbf{5} \cdot \mathrm{BPh}_{4}$ showed two absorption bands at 1602 and $1424 \mathrm{~cm}^{-1}$, attributable to the symmetric and antisymmetric stretching frequencies of a $\mu_{1,3}$-bridging formate ion. This was also confirmed by an X-ray crystal structure determination of $\mathbf{5} \cdot \mathbf{B P h}_{4}$ (Figure 3 ). The electronic absorption spectra of 5 exhibits two weak absorption bands at 651 and $1114 \mathrm{~nm}$ which can be assigned to the spin-allowed ${ }^{3} \mathrm{~A}_{2 \mathrm{~g}} \rightarrow{ }^{3} \mathrm{~T}_{1 \mathrm{~g}}\left(v_{2}\right)$ and ${ }^{3} \mathrm{~A}_{2 \mathrm{~g}} \rightarrow{ }^{3} \mathrm{~T}_{2 \mathrm{~g}}\left(v_{1}\right)$ transitions of a nickel(II) $(\mathrm{S}=1)$ ion in $\mathrm{O}_{\mathrm{h}}$ symmetry [37]. There is also a weak shoulder around 910 $\mathrm{nm}$ attributable to a spin-forbidden ${ }^{3} \mathrm{~A}_{2 \mathrm{~g}} \rightarrow{ }^{1} \mathrm{E}_{\mathrm{g}}(\mathrm{D})$ transition which gains intensity due to the lowering of the symmetry. The ${ }^{3} \mathrm{~A}_{1 \mathrm{~g}} \rightarrow{ }^{3} \mathrm{~T}_{\mathrm{lg}}(\mathrm{P})$ transition (expected below $400 \mathrm{~nm}$ ) is obscured in each case by the strong thiolate-to-Ni(II) LMCT transitions which occur in the same spectral region.

In summary, we have prepared the first stable dinuclear nickel(II) borohydrido-bridged complex of a macrodinucleating hexaaza-dithiophenolate ligand. Work in progress is directed towards the synthesis of related compounds with bridging hydride ligands by taking advantage of the steric protection offered by the supporting ligand. Such compounds may also aid in understanding the electronic structures and the reactivities of the dinuclear active sites of the hydrogenase enzymes.

\section{Macrocyclic dinickel(II) complexes colligated by hydrosulfide and hexasulfide ions}

So far, our studies have been confined to complexes bearing different coligands, we have now examined the capability of the $\left[(\mathrm{L}) \mathrm{Ni}_{2}\right]^{2+}$ fragment to bind as coligand hydrosulfide $\left(\mathrm{HS}^{-}\right)$. Our motivation in this area are diverse and include: a) hydrosulfide complexes of labile transition-metal ions are rather scarce [60-64]; b) the hydrosulfide ion is a biologically relevant molecule [65]; c) nickel sulfur bonding is of importance in bioinorganic [66-68] and biomimetic chemistry [69-70]; d) the chemistry of $\mathrm{SH}^{-}$- containing complexes is of relevance to metal sulfide hydrosulfurization catalysts [71-73]; and e) coligands with "soft" donor atoms have not been incorporated in the binding pocket of the $\left[\mathrm{M}_{2}^{\mathrm{II}} \mathrm{L}\right]^{\mathrm{n}+}$ complexes.

A general problem associated with the preparation of hydrosulfide complexes is further aggregation which leads to the formation of polynuclear sulfido complexes and eventually to insoluble metal sulfides. Herein we demonstrate that the sterically demanding supporting ligand $\mathrm{L}^{2-}$ enables the isolation and characterization of the stable hydrosulfide. The synthetic procedures are depicted in Scheme 1. 


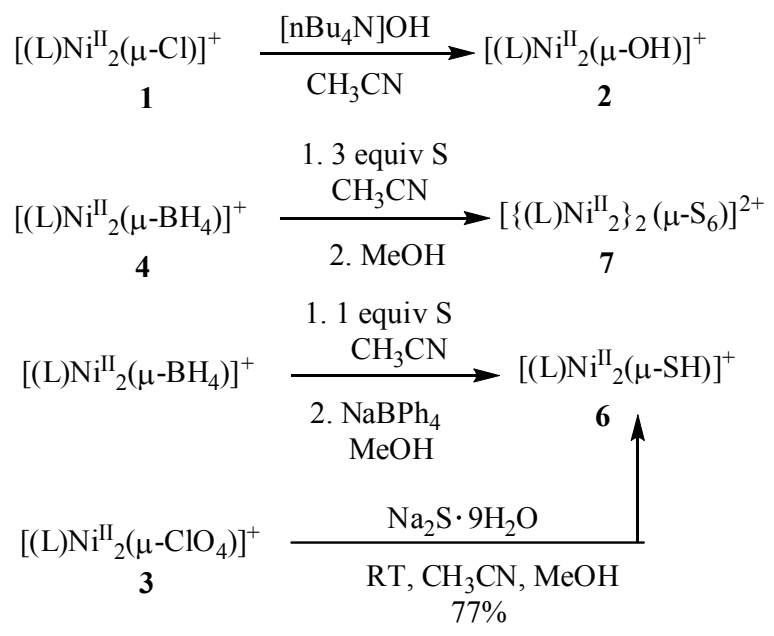

Scheme 1. Preparation of complexes 6 and 7.

Initial attempts aimed at the synthesis of the hydrosulfide complex $\left[\mathrm{Ni}_{2} \mathrm{~L}(\mathrm{SH})\right]^{+}(\mathbf{6})$ followed the method of preparing the hydroxide complex $\left[\mathrm{Ni}_{2} \mathrm{~L}(\mathrm{OH})\right]^{+}(\mathbf{2})$ from $\left[\mathrm{Ni}_{2} \mathrm{~L}(\mathrm{Cl})\right]^{+}(\mathbf{1})$ and $\left(\mathrm{n}-\mathrm{Bu}_{4} \mathrm{~N}\right) \mathrm{OH}$, [27] but surprisingly, 1 proved to be substitutionally inert in reactions with $\mathrm{Na}_{2} \mathrm{~S} \cdot 9 \mathrm{H}_{2} \mathrm{O}$ or $\left(\mathrm{Et}_{4} \mathrm{~N}\right) \mathrm{SH}$ [74]. The reduction of elemental sulfur by the borohydride complex $\left[\mathrm{Ni}_{2}{ }_{2} \mathrm{~L}\left(\mathrm{BH}_{4}\right)\right]^{+}(4)$ [75] was sought as an alternative procedure. Indeed, when green $\mathbf{4} \cdot \mathrm{ClO}_{4}$ was treated with 1 equiv of $\mathrm{S}$ powder in $\mathrm{CH}_{3} \mathrm{CN}$, a yellow-brown solution forms immediately, and the desired hydrosulfide complex 6 can be isolated from methanol as a brown-yellow $\mathrm{ClO}_{4}^{-}$salt in $>70 \%$ yields. This reaction presumably involves thioborate/polysulfide intermediates (as in the $\mathrm{LiBH}_{4} / \mathrm{S}_{8}$ system) $[76,77]$ which hydrolyze during workup to produce hydrosulfide anions which are trapped by the $\left[\mathrm{Ni}^{\mathrm{II}}{ }_{2} \mathrm{~L}\right]^{2+}$ fragment. It should be noted that complex 6 is also obtained, in similarly high yields, from reactions in acetonitrile of the extreme labile perchlorato complex $\left[\mathrm{Ni}_{2} \mathrm{~L}\left(\mathrm{ClO}_{4}\right)\right]$ $\mathrm{ClO}_{4}\left(3 \cdot \mathrm{ClO}_{4}\right)$ with 1 equiv of $\mathrm{Na}_{2} \mathrm{~S} \cdot 9 \mathrm{H}_{2} \mathrm{O}$, followed by workup from methanol. That polysulfide ions are indeed involved in these transformations was confirmed by the isolation of the hexasulfide complex $\left[\left\{\mathrm{Ni}_{2} \mathrm{~L}\right\}_{2}\left(\mu-\mathrm{S}_{6}\right)\right]\left(\mathrm{BPh}_{4}\right)_{2}\left(7 \cdot\left(\mathrm{BPh}_{4}\right)_{2}\right)$. This material could be reproducibly obtainned in yields as high as $70 \%$ when elemental sulfur is reacted with $\mathbf{4} \cdot \mathrm{ClO}_{4}$ in $\mathrm{MeCN}$ in a 3:1 molar ratio followed by workup from wet methanol as indicated in Scheme 1. At larger (4:1) or smaller (2:1) $\mathrm{S} / 3$ ratios a yellow-brown solid of unknown composition precipitates. The complexes $\mathbf{6}$ and $\mathbf{7}$ are stable for weeks in the absence of air and protic reagents both in the solid state and in solution. This stability is quite remarkable given that hydrosulfide complexes of sterically less demanding ligands are readily transformed into polysulfides or metal sulfides [63]. In the presence of air the yellow-brown color of solutions of $\mathbf{6}$ and $\mathbf{7}$ fades away within about $24 \mathrm{~h}$ and green products of unknown compositions precipitate.

The ESI-MS of a freshly prepared acetonitrile solution of $\mathbf{6}$ shows two nickel-containing fragments at $\mathrm{m} / \mathrm{z}=472.68$ and 412.68 neither of which is the parent peak. The infrared spectrum of $6 \cdot \mathrm{BPh}_{4}$ shows a weak sharp $v(\mathrm{SH})$ band at $2552 \mathrm{~cm}^{-1}$ typical for complexes with $\mathrm{SH}^{-}$groups [78]. For 7·( $\left(\mathrm{BPh}_{4}\right)_{2}$ two weak IR bands appeared at 468 and 440 $\mathrm{cm}^{-1}$, attributable to the S-S stretching modes of the $\mathrm{S}_{6}{ }^{2-}$ unit. These values agree well with those reported for $\mathrm{K}_{2} \mathrm{~S}_{6}$ and other compounds with a $\mathrm{S}_{6}{ }^{2-}$ unit [79]. Electronic absorption spectra for $\mathbf{6} \cdot \mathrm{ClO}_{4}$ and $7 \cdot\left(\mathrm{ClO}_{4}\right)_{2}$ complexes feature three intense absorption maxima in the UV at $\sim 270 \mathrm{~nm}, \sim 300 \mathrm{~nm}$, and $330 \mathrm{~nm}$. These are characteristic for nickel complexes of $\mathrm{L}^{2-}$. The former two can be attributed to $\pi-\pi^{*}$ transitions within the aromatic rings of the supporting ligand whereas the latter corresponds to a thiophenolate $\rightarrow \mathrm{Ni}^{\mathrm{II}}$ charge transfer absorption. Unfortunately, the ligand-to-metal charge transfer (LMCT) bands involving the $\mathrm{SH}^{-}$and $\mathrm{S}_{6}^{2-}$ groups are not resolved. Above $500 \mathrm{~nm}$ complex 4 exhibits two weak absorption bands at 663 and $1175 \mathrm{~nm}$ which can be assigned to the spin-allowed ${ }^{3} \mathrm{~A}_{2 \mathrm{~g}} \rightarrow{ }^{3} \mathrm{~T}_{1 \mathrm{~g}}\left(v_{2}\right)$ and ${ }^{3} \mathrm{~A}_{2 \mathrm{~g}} \rightarrow{ }^{3} \mathrm{~T}_{2 \mathrm{~g}}\left(v_{1}\right)$ transitions of a nickel(II) $(\mathrm{S}=1)$ ion in $\mathrm{O}_{\mathrm{h}}$ symmetry [80]. The corresponding values for $\mathbf{6}$ are significantly blue-shifted to 647 and $1102 \mathrm{~nm}$, respectively. The ${ }^{3} \mathrm{~A}_{1 \mathrm{~g}} \rightarrow{ }^{3} \mathrm{~T}_{1 \mathrm{~g}}(\mathrm{P})$ transition (expected below $400 \mathrm{~nm}$ ) is obscured in each case by the strong LMCT transitions. From the $v_{1}$ transition one can obtain rough estimates of the octahedral splitting parameters $\Delta_{\text {oct }}$ for $4\left(\approx 8511 \mathrm{~cm}^{-1}\right)$ and for $\mathbf{6}\left(\approx 9074 \mathrm{~cm}^{-1}\right)$, respectively. Such low values for $\Delta_{\text {oct }}$ (i.e., $\left.\Delta_{\text {oct }}(\mathbf{4}, \mathbf{6})<\Delta_{\text {oct }}\left[\mathrm{Ni}\left(\mathrm{H}_{2} \mathrm{O}\right)_{6}\right]^{2+}\right)$ $\left.8500 \mathrm{~cm}^{-1}\right)$ are quite typical for $\mathrm{N}_{3} \mathrm{Ni}^{\mathrm{II}}(\mu-\mathrm{SR})_{3}$ chromophores [81]. In general, thiolates induce only weak ligand field strengths because of their poor $\sigma$-donor bonding abilities. The same is true for the $\mathrm{SH}^{-}$and $\mathrm{S}_{6}{ }_{6}^{2-}$ ligands as indicated by the data in Table 2. Complexes $\mathbf{4}$ and $\mathbf{6}$ have the lowest $\Delta_{\text {oct }}$ values. The $\Delta_{\text {oct }}$ value for the $\left[(\mathrm{L}) \mathrm{Ni}_{2}(\mu-\mathrm{SPh})\right]^{+}$complex 8 $\left(8764 \mathrm{~cm}^{-1}\right)$ lies between the values of 4 and $\mathbf{6}$. On the basis of these data, the $\sigma$-donor bonding ability of the SR-groups can be ranked as follows: $\mathrm{S}_{6}^{2-}>\mathrm{SPh}^{-}>\mathrm{SH}^{-}$. 
Selected UV/Vis Data for complexes 1-4 and 6-8

Table 2

\begin{tabular}{|l|l|l|l|l|}
\hline complex & coligand & $\mathbf{v}_{\mathbf{2}} / \mathbf{n m}$ & $\mathbf{v}_{\mathbf{1}} / \mathbf{n m}$ & $\Delta_{\mathbf{0}} / \mathbf{c m}^{-1}$ \\
\hline $1^{\mathrm{a}}$ & $\mathrm{Cl}^{-}$ & $658(41)$ & $998(67)$ & 10020 \\
\hline $2^{\mathrm{a}}$ & $\mathrm{OH}^{-}$ & $655(52)$ & $1056(40)$ & 9470 \\
\hline $3^{\mathrm{b}}$ & $\mathrm{ClO}_{4}^{-}$ & $578(129)$ & $1066(86)$ & 9381 \\
\hline $4^{\mathrm{a}}$ & $\mathrm{BH}_{4}^{-}$ & $650(43)$ & $1074(77)$ & 9311 \\
\hline $6^{\mathrm{b}}$ & $\mathrm{SH}^{-}$ & $663(32)$ & $1175(49)$ & 8511 \\
\hline $7^{\mathrm{b}}$ & $\mathrm{S}_{6}{ }^{-}$ & $647(56)$ & $1102(72)$ & 9074 \\
\hline $8^{\text {a }}$ & $\mathrm{SPh}^{-}$ & $667(52)$ & $1141(68)$ & 8764 \\
\hline
\end{tabular}

The structures of complexes 6 and 7 were further substantiated by X-ray crystallography. The atomic numbering scheme used for the central $\mathrm{N}_{3} \mathrm{Ni}(\mu-\mathrm{S})_{3} \mathrm{NiN}_{3}$ core in $\mathbf{6}$ was also applied for 7 to facilitate structural comparisons. The structure determination of $\left[\mathrm{Ni}_{2} \mathrm{~L}(\mathrm{SH})\right] \mathrm{BPh}_{4} \cdot \mathrm{MeOH} \cdot 2 \mathrm{H}_{2} \mathrm{O}$ unambiguously confirmed the presence of the cationic hydrosulfide complex $\left[\mathrm{Ni}_{2} \mathrm{~L}(\mu-\mathrm{SH})\right]^{+}$(Figure 4).

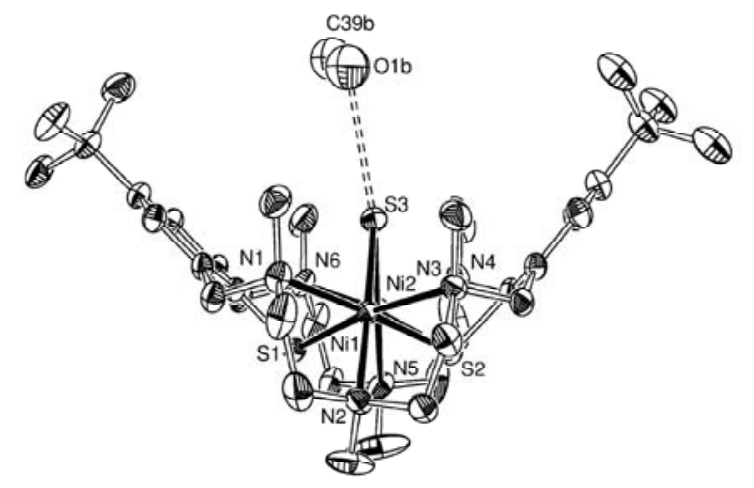

Fig. 4. Structure of the hydrosulfide complex 6 in crystals of $6 \cdot \mathrm{BPh} \cdot \mathrm{MeOH} \cdot 2 \mathrm{H}_{2} \mathrm{O}$. Hydrogen atoms are omitted for reasons of clarity. The dashed line indicates a hydrogen bond between the $\mathrm{SH}$ moiety and the $\mathrm{MeOH}$ solvate

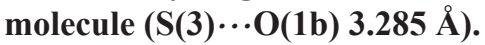

Although the SH hydrogen atom could not be located from difference Fourier electron density maps, its presence is implied by IR spectroscopy and charge considerations (assuming the presence of one dianionic $\mathrm{L}^{2-}$, one $\mathrm{BPh}_{4}^{-}$, one $\mathrm{SH}^{-}$, and two $\mathrm{Ni}^{2+}$ ions). There is also a $\mathrm{MeOH}$ solvate molecule that lies in the vicinity of the $\mathrm{SH}$ unit $(\mathrm{S} \cdots \mathrm{OMeOH}$ $3.285 \AA$ ) indicative of a weak $\mathrm{SH} \cdots \mathrm{OMeOH}$ hydrogen bond [82,83]. Unlike in isoelectronic $\left[(\mathrm{L}) \mathrm{Ni}_{2}(\mu-\mathrm{Cl})\right]^{+}(\mathbf{1})$ or in $\left[(\mathrm{L}) \mathrm{Ni}_{2}(\mu-\mathrm{OH})\right]^{+}(2)$, the macrocycle adopts the bowl-shaped conformation B as observed in $\left[(\mathrm{L}) \mathrm{Ni}_{2}\left(\mu-\mathrm{ClO}_{4}\right)\right]^{+}(\mathrm{see}$ Figure 1 for a schematic representation of the two conformations) [47]. The presence of the type $\mathrm{B}$ conformation of $\mathrm{L}^{2-}$ in 4 presumably relates to the larger ionic radii of the $\mathrm{SH}$-group $\left(\mathrm{OH}^{-}: 1.19 \AA, \mathrm{Cl}^{-}: 1.67 \AA, \mathrm{SH}^{-}: 1.93 \AA\right)$ [84]. Previous work has shown that the conformation of $\mathrm{L}^{2-}$ is coupled to the size of the coligand $\mathrm{L}^{\prime}$ in the $\left[\mathrm{Ni}_{2} \mathrm{~L}\left(\mathrm{~L}^{\prime}\right)\right]^{+}$ complexes $[28,85] \mathrm{L}^{2-}$ adopts the bowl-shaped conformation when $\mathrm{L}^{\prime}$ is large, the driving force being the more regular octahedral coordination environment about the $\mathrm{Ni}^{2+}$ ions. Similar arguments can be used to explain the different structures of 1, 2, and $\mathbf{6}$ (which bear all single-atom bridging ligands). Thus, upon going from the $\mu$-OH complex 2 to the $\mu-\mathrm{Cl}$ complex 1 the macrocycle maintains conformation A and the deviations of the L-M-L angles from the ideal values increase; particularly affected are the N-M-X trans angles. On the other hand, upon going from 2 to the SH complex 6, $\mathrm{L}^{2-}$ changes its conformation and the $\mathrm{NiN}_{3} \mathrm{~S}_{3}$ polyhedra become more regular. A number of dinuclear nickel complexes with $\mu$-SR groups have been reported in the literature [86,87]. Pohl has reported a dinickel complex with two bridging SH groups [88]. As far as we are aware, $\mathbf{6}$ is the first dinickel complex with a single $\mu$-SH group. The average $\mathrm{Ni}$-SR (thiolate) bond length of 2.479(1) $\AA$ in 6 is quite typical for six-coordinate $\mathrm{Ni}^{\mathrm{iI}}$ thiolate complexes. For example, the $\mathrm{Ni}-\mu-\mathrm{SPh}$ bonds in the octahedral complexes $\left[\mathrm{Ni}(\text { terpy })(\mu-\mathrm{SPh})_{2}\right]_{2} \cdot 6 \mathrm{MeOH}[89]$ and $\left[(\mathrm{L}) \mathrm{Ni}_{2}(\mu-\mathrm{OAc})\right] \mathrm{BPh} \mathrm{H}_{4}[90] \mathrm{are}$ 2.465(2) $\AA$ and 2.471(1) $\AA$ long, respectively. However, the Ni- $\mu$-SH distances in 6 (mean 2.527(1) $\AA$ ) are significantly longer than the $\mathrm{Ni}-\mu-\mathrm{SR}$ (thiolate) bonds. This is in good agreement with the notion that the $\mathrm{SH}^{-}$ligands are weaker $\sigma$-donors than thiophenolates. It should be noted that the $\mathrm{Ni} \cdots \mathrm{Ni}$ distance in $\mathbf{6}$ at 3.295(1) $\AA$ is quite long for complexes containing face-sharing $\mathrm{N}_{3} \mathrm{Ni}(\mu-\mathrm{SR})_{3} \mathrm{NiN}_{3}$ structures. In the trinuclear complexes $\left[\left\{\mathrm{Ni}_{2} \mathrm{~L}^{\prime \prime}\right\}_{2} \mathrm{Ni}^{+}\right.$and $\left[\left\{\mathrm{Ni} \mathrm{L}^{\prime \prime}\right\}_{2} \mathrm{Ni}\right]^{2+}$ 
(L".- octadentate $\mathrm{N}_{3} \mathrm{~S}_{3}$ ligand), the nickel atoms are separated by only 3.008(2) and 3.029(1) $\AA$ [91]. Likewise, for $\left[\mathrm{Ni}_{2} \mathrm{~L}^{\prime \prime}{ }_{3}\right]^{2+}\left(\mathrm{L}^{\prime \prime \prime}\right.$ - tridentate $\mathrm{N}_{2} \mathrm{~S}$ ligand) the $\mathrm{Ni} \cdots \mathrm{Ni}$ distance is 3.064(1) $\AA$ [92]. The Ni-S-Ni angles in these complexes range from 78.9 to $80.16^{\circ}$ and are thus more obtuse than in $6\left(83.3-81.4^{\circ}\right)$.

The crystal structure of $\left[\left\{\mathrm{Ni}_{2} \mathrm{~L}\right\}_{2}\left(\mathrm{~S}_{6}\right)\right] \cdot\left(\mathrm{BPh}_{4}\right)_{2} \cdot 5 \mathrm{MeCN}\left(7 \cdot\left(\mathrm{BPh}_{4}\right)_{2} \cdot 5 \mathrm{MeCN}\right)$ consists of discrete tetranuclear $\left[\left\{\mathrm{Ni}_{2} \mathrm{~L}\right\}_{2}\left(\mu-\mathrm{S}_{6}\right)\right]^{2+}$ dications, tetraphenylborate anions, and acetonitrile solvate molecules. Figure 5 provides an ORTEP view of the structure of 7. Two dinuclear $\left[\mathrm{Ni}_{2} \mathrm{~L}\right]$ subunits are linked via a helical $\mathrm{S}_{6}{ }^{2-}$ chain. Again, both $\left[\mathrm{Ni}_{2} \mathrm{~L}\right]^{2+}$ subunits feature a bowl-shaped conformation for reasons likely to be similar to those detailed above for $\mathbf{6}$. The average S-S bond length is 2.065(2) $\AA$, and the dihedral S-S-S-S angles range from 76.4 to $94.3^{\circ}$. Similar values are observed in plastic sulphur [93] and other $\mathrm{S}_{6}{ }^{2-}$ systems [94,95]. It should be noted that the $\mathrm{Ni}-\mu-\mathrm{S}_{6}$ bond lengths in 7 (mean 2.479(2) $\AA$ ) are significantly shorter than the Ni- $\mu$-SH bonds in 6 averaging 2.527(1) $\AA$, an observation that correlates nicely with the stronger $\sigma$-bonding ability of the $\mathrm{S}_{6}{ }^{2-}$ ion (vide infra). There are no unusual features as far as bond lengths and angles of the $\left[\mathrm{Ni}_{2} \mathrm{~L}\right]^{2+}$ units are concerned. The average Ni-N (2.262(7) $\AA$ ) and Ni-S (2.498(2) $\left.\AA\right)$ bond lengths in 6 are similar to the values of the compound above. There are no significant intermolecular interactions between the $\mathrm{Ni}_{4}{ }_{4}$ complexes within the lattice. The shortest intermolecular $\mathrm{Ni} \cdots \mathrm{Ni}$ distance is at 7.711(1) $\AA$. The present coordination mode of the $\mathrm{S}_{6}{ }^{2-}$ dianion linking two binuclear $\mathrm{N}_{3} \mathrm{Ni}(\mu-\mathrm{SR})_{2} \mathrm{NiN}_{2}$ cores is also without precedence in the literature.

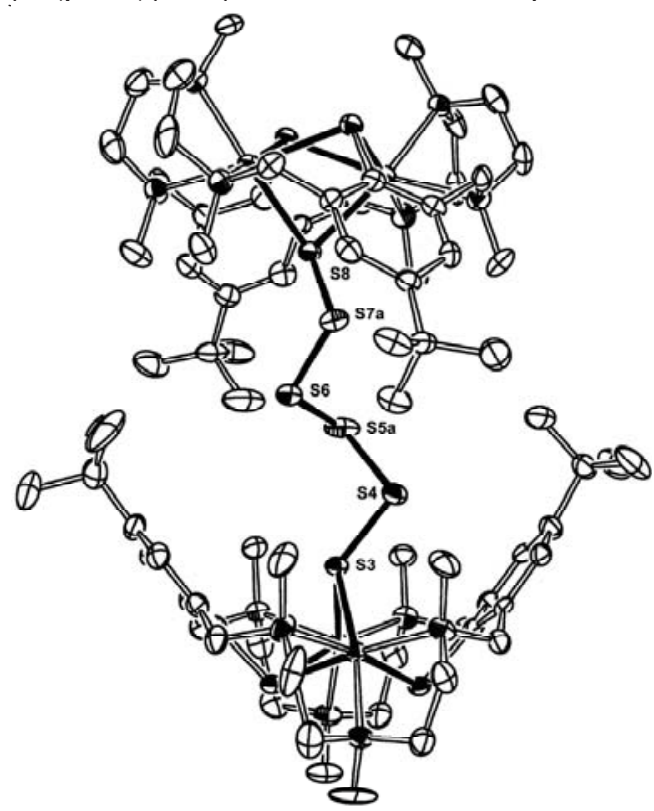

Fig. 5. Structure of the $\left[\left\{(\mathrm{L}) \mathrm{Ni}_{2}\right\}_{2}\left(\mu-\mathrm{S}_{6}\right)\right]^{2+}$ dication in crystals of $7 \cdot\left(\mathrm{BPh}_{4}\right)_{2} \cdot 5 \mathrm{MeCN}$. Thermal ellipsoids are drawn at the $30 \%$ probability level. Only one orientation of the disordered $\mathrm{S}_{6}^{2-}$ unit is displayed. Hydrogen atoms are omitted

The main findings of these investigations can be summarized as follows: (a) the steric protection-offered by the supporting ligand $\mathrm{L}^{2-}$ allows for the preparation and isolation of stable hydrosulfide complexes of labile transition metal ions; (b) the $\left[(\mathrm{L}) \mathrm{Ni}_{2}\left(\mu-\mathrm{BH}_{4}\right)\right]^{+}$complex reacts rapidly with elemental sulfur and represents a versatile starting material for $\left[(\mathrm{L}) \mathrm{Ni}_{2}(\mu-\mathrm{SH})\right]^{+} ;$(c) polysulfide complexes such as $\left[\left\{(\mathrm{L}) \mathrm{Ni}_{2}\right\}_{2}\left(\mu-\mathrm{S}_{6}\right)\right]^{2+}$ are also accessible from $\left[(\mathrm{L}) \mathrm{Ni}_{2}\left(\mu-\mathrm{BH}_{4}\right)\right]^{+}$and $\mathrm{S}_{8} ;(d)$ unlike in $\left[(\mathrm{L}) \mathrm{Ni}_{2}(\mu-\mathrm{Cl})\right]^{+}$or in $\left[(\mathrm{L}) \mathrm{Ni}_{2}(\mu-\mathrm{OH})\right]^{+}$, the larger $\mathrm{SH}^{-}$and $\mathrm{S}_{6}{ }_{6}^{-}$ions induce the bowl-shaped macrocycle conformation of type $\mathrm{B}$; (e) the $\mathrm{SH}^{-}$and $\mathrm{S}_{6}{ }^{2}-$ ions groups are characterized by their poor $\sigma$-donor bonding abilities.

\section{Trapping of monomethyl orthomolybdate in the binding pocket of the $\left[(\mathrm{L}) \mathrm{Co}_{2}{ }_{2}\right]^{2+}$ fragment}

The synthesis and structural characterization of a large number of polynuclear oxo-alkoxo species of hexavalent Mo have been reported. Typical examples are polymeric $\left[\mathrm{Mo}_{2} \mathrm{O}_{5}(\mathrm{OMe})_{2}\right]$ [96], tetranuclear $\left[\mathrm{Mo}_{4} \mathrm{O}_{10}(\mathrm{OMe})_{6}\right]^{2-}[97]$, and octanuclear $\left[\mathrm{Mo}_{8} \mathrm{O}_{24}(\mathrm{OMe})_{4}\right]^{4-}[98]$, which can be readily prepared by solvolysis reactions of soluble isopolymolybdate anion precursors, such as $\left(n-\mathrm{Bu}_{4} \mathrm{~N}\right)_{2}\left[\mathrm{Mo}_{2} \mathrm{O}_{7}\right]$ and $\left(n-\mathrm{Bu}_{4} \mathrm{~N}\right)_{4}\left[\mathrm{Mo}_{8} \mathrm{O}_{28}\right]$, in methanol [99]. While the coordination chemistry of the polynuclear oxo-alkoxo molybdates is now fairly well-understood [100], surprisingly little is known about their monomeric $\mathrm{Mo}^{\mathrm{v} I} \mathrm{O}_{x}(\mathrm{OR})_{y}$ congeners. In particular, four coordinate molybdenum oxoalkoxides are difficult to stabilize. The neutral alkyl esters, $\mathrm{MoO}_{2}(\mathrm{OR})_{2}$, bearing primary alkoxy groups $(\mathrm{R}=\mathrm{Me}, \mathrm{Et}, \mathrm{Pr})$ are Lewis acidic [101] and tend to oligomerize in the solution as well as in the solid state [102]. Monomeric, four-coordinate species, such as $\mathrm{MoO}_{2}(\mathrm{O}-t-\mathrm{Bu})_{2}$ [103], $\mathrm{MoO}_{2}\left(\mathrm{OSiPh}_{3}\right)_{2}$ [104], and $\mathrm{MoO}_{2}\left(\mathrm{O}-2,6-t-\mathrm{Bu}_{2} \mathrm{C}_{6} \mathrm{H}_{3}\right)_{2}$ [105], are only accessible with bulky alkoxides. The same is true for the anionic $\mathrm{MoO}_{3}(\mathrm{OR})$ - compounds. Stable species, such as $\left[\mathrm{MoO}_{3}\left(\mathrm{OSi}-t-\mathrm{Bu}_{3}\right)\right]^{-}[106]$, 
do exist but only with bulky ligands [107,108]. Our study was initiated by the finding that tetrahedral oxoanions, such as $\mathrm{ClO}_{4}^{-}$[47] and $\mathrm{H}_{2} \mathrm{PO}_{4}^{-}[29]$ can be readily accommodated in the binding pocket of the dinuclear $\left[(\mathrm{L}) \mathrm{M}_{2}\right]^{2+}$ complexes. This led us to study the ability of the $\left[\left(\mathrm{L}_{\mathrm{M}} \mathrm{M}_{2}\right]^{2+}\right.$ fragment to bind tetrahedral oxoanions of the transition metals [109]. In the course of our studies, we have been able to trap the elusive $\mathrm{MoO}_{3}(\mathrm{OMe})^{-}$ion.

The neutral $\mathrm{Co}_{2}{ }_{2}$ complex 10 was chosen as the target compound. Following the method of preparation of $[(\mathrm{L})$ $\left.\mathrm{Ni}_{2}\left(\mathrm{O}_{2} \mathrm{P}-(\mathrm{OH})_{2}\right)\right]^{+}$from $\left[(\mathrm{L}) \mathrm{Ni}_{2}(\mathrm{Cl})\right]^{+}$and $\left(n-\mathrm{Bu}_{4} \mathrm{~N}\right) \mathrm{H}_{2} \mathrm{PO}_{4}[29], \mathbf{1}$ was treated with $\left(n-\mathrm{Bu}_{4} \mathrm{~N}\right)_{2} \mathrm{MoO}_{4},[110,111]$ in $\mathrm{CH}_{3} \mathrm{CN}$ at ambient temperature for $12 \mathrm{~h}$, as indicated in Scheme 2, to yield $\mathbf{1 0}$ as a pale-red powder. Recrystallization from dichloromethane/ethanol produced analytically pure material in $84 \%$ yield.

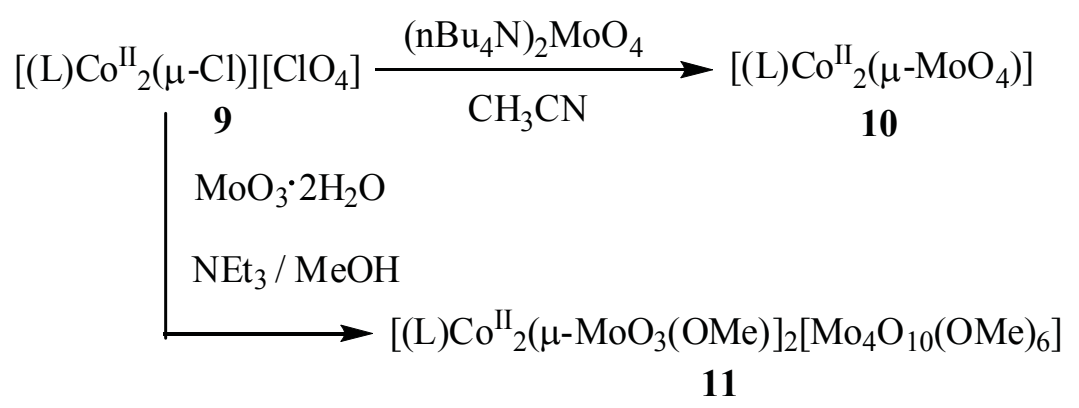

Scheme 2. Synthesis of complexes 10 and 11.

In another attempt, we tried to synthesize $\mathbf{1 0}$ by the direct reaction of $\mathbf{9}$ with an excess of $\left(\mathrm{HNEt}_{3}\right)_{2} \mathrm{MoO}_{4}$ (prepared in situ from $\mathrm{MoO}_{3} \cdot 2 \mathrm{H}_{2} \mathrm{O}$ and $\mathrm{NEt}_{3}$ ) $[112,113]$ in methanol, but this resulted in the formation of 11, which was reproducibly obtained as a dark-red-brown microcrystalline solid in ca. $45 \%$ yield. Attempts to generate a similar product by methanolysis of $\mathbf{9}$ have failed. Thus, the formation of $\mathbf{1 1}$ is simply a matter of trapping this species from solution.

The IR spectrum of 10 in $\mathrm{KBr}$ shows three strong absorptions at 861,848 , and $807 \mathrm{~cm}^{-1}$, which are tentatively assigned to the $v_{1}\left(\mathrm{~A}_{1}\right)$ and $v_{3}\left(\mathrm{~F}_{2}\right)$ stretching modes of the $\mathrm{MoO}_{4}^{2-}$ unit [114]. The splitting of $v_{3}$ can be traced back to the lower local symmetry of the $\eta^{2}$-bonded $\mathrm{MoO}_{4}{ }^{2-}$ ion (see the crystal structure described below). The IR spectrum of 11 exhibits several absorbances in the 950-678 $\mathrm{cm}^{-1}$ region. The bands at 941, 913, 880, 751, and $678 \mathrm{~cm}^{-1} \mathrm{can}$ be assigned to the various Mo-O stretching frequencies of the $\left[\mathrm{Mo}_{4} \mathrm{O}_{10}(\mathrm{OMe})_{6}\right]^{2-}$ anion. Similar values have been reported for $\left[\mathrm{Ph}_{3} \mathrm{MeP}\right]_{2}\left[\mathrm{Mo}_{4} \mathrm{O}_{10}\left(\mathrm{OCH}_{3}\right)_{6}\right]$ [100]. The two remaining absorptions at 803 and $818 \mathrm{~cm}^{-1}$ can then be attributed to the Mo-O stretching modes of the $\left[\mathrm{MoO}_{3}\left(\mathrm{OCH}_{3}\right)\right]^{-}$unit, but these values should be taken as indicative rather than definitive. There may be further bands associated with the coligand that are obscured by the $\left[\mathrm{Mo}_{4} \mathrm{O}_{10}(\mathrm{OMe})_{6}\right]^{2-}$ absorptions. The UV/vis spectrum of $\mathbf{1 0}$ is very similar to that of $\mathbf{9}$, displaying typical weak d-d transitions of octahedral high spin $\mathrm{Co}^{\text {II }}$ in the 300-1600 nm range [90]. The weak broad band at $1307 \mathrm{~nm}$ can be assigned to the ${ }^{4} T_{1 \mathrm{~g}}(\mathrm{~F}) \rightarrow{ }^{4} T_{2 \mathrm{~g}}$ transition. The features in the 500-630 $\mathrm{nm}$ region are attributable to components of the parent octahedral ${ }^{4} T_{1 \mathrm{~g}}(\mathrm{~F}) \rightarrow{ }^{4} T_{1 \mathrm{~g}}(\mathrm{P})$ and ${ }^{4} T_{1 \mathrm{~g}}(\mathrm{~F}) \rightarrow{ }^{4} A_{2 \mathrm{~g}}$ ligand field transitions split by lower symmetry.

In view of the air stability of $\mathbf{1 0}$, it was of interest to determine its redox properties. Figure 6 shows its cyclic voltammogram in a dichloromethane solution. Two waves, one at $E_{1 / 2}^{1}=+0.10 \mathrm{~V}$ (vs SCE) with a peak-to-peak separation of $140 \mathrm{mV}$ and one at $E_{1 / 2}^{2}=+0.55 \mathrm{~V}$ with a peak-to-peak separation of $146 \mathrm{mV}$, are observed. These oxidations correspond to metal-centered oxidations of the $\mathrm{Co}^{\mathrm{II}} \mathrm{Co}^{\mathrm{II}}$ species 10 to its mixed-valent $\mathrm{Co}^{\mathrm{II}} \mathrm{Co}^{\mathrm{III}}$ and fully oxidized $\mathrm{Co}^{\mathrm{III}} \mathrm{Co}^{\mathrm{III}}$ forms (eqs 1 and 2 , respectively). Thus, as was observed previously for $\mathbf{9}$, the divalent $\mathrm{Co}^{\mathrm{II}}$ oxidation level is enormously stabilized over the trivalent state. Likewise, within our potential window, no reductions of the $\mathrm{MoO}_{4}^{2-}$ ion are detected.

$$
\begin{array}{llcl}
{\left[(\mathrm{L}) \mathrm{Co}^{\mathrm{III}} \mathrm{Co}^{\mathrm{II}}\left(\mathrm{MoO}_{4}\right)\right]^{+}+\mathrm{e}^{-}} & \leftrightarrow & {\left[(\mathrm{L}) \mathrm{Co}^{\mathrm{II}}\left(\mathrm{MoO}_{4}\right)\right]} & E^{1} \\
{\left[(\mathrm{~L}) \mathrm{Co}^{\mathrm{III}} \mathrm{Co}^{\mathrm{III}}\left(\mathrm{MoO}_{4}\right)\right]^{2+}+\mathrm{e}^{-}} & \leftrightarrow & {\left[(\mathrm{L}) \mathrm{Co}^{\mathrm{III}} \mathrm{Co}^{\mathrm{II}}\left(\mathrm{MoO}_{4}\right)\right]^{+}} & E^{2} \\
{ }_{1 / 2}
\end{array}
$$

The normal potentials for $\mathbf{1 0}$ are slightly shifted to more negative potentials when compared with those of the acetate-bridged complex $\left[(\mathrm{L}) \mathrm{Co}_{2}{ }_{2}(\mu-\mathrm{OAc})\right]^{+}\left(E_{1 / 2}^{1}=0.21 \mathrm{~V} ; E_{1 / 2}^{2}=0.60 \mathrm{~V}\right)[30]$. These differences are likely a consequence of the charge differences. Recall that 10 is a neutral species whereas $\left[(\mathrm{L}) \mathrm{Co}_{2}{ }_{2}(\mu-\mathrm{OAc})\right]^{+}$is a mono-cation. It should be noted that the oxidized species are only stable on the time scale of a cyclic voltammetry experiment. All attempts to prepare these compounds by electrochemical or chemical oxidation led to unidentified decomposition products. Thus, while some of the above oxidations appear electrochemically reversible, they are all chemically irreversible. 


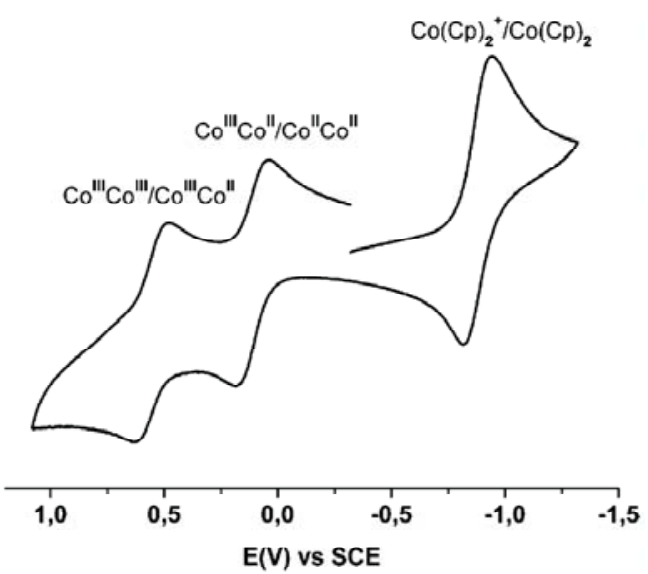

Fig. 6. Cyclic voltammogram of 10 in dichloromethane at $295 \mathrm{~K}$.

The X-ray crystal structures of complexes 10 and $\mathbf{1 1} \cdot 6 \mathrm{MeOH}$ were determined to establish the geometries about the metal ions as well as the bonding modes of the coligands.

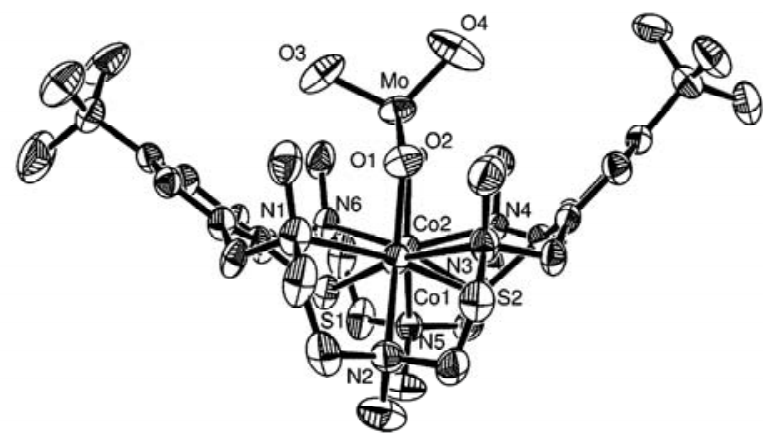

Fig. 7. Structure of the neutral complex 10 in crystals of $10 \cdot \mathrm{CH}_{2} \mathrm{Cl}_{2}$. Thermal ellipsoids are drawn at the $50 \%$ probability level. $H$ atoms are omitted for reasons of clarity.

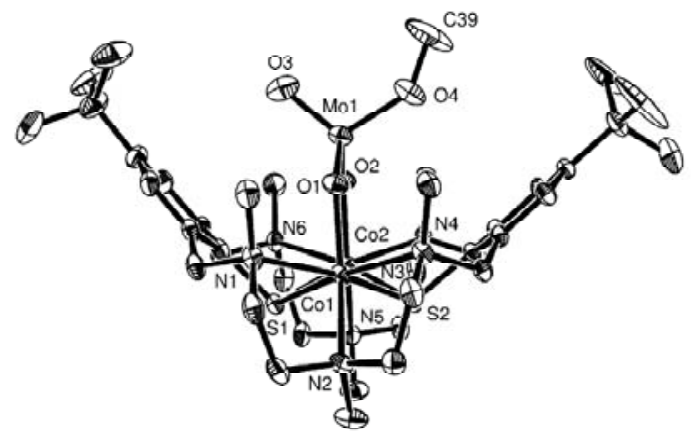

Fig. 8. Structure of the $\left[(\mathrm{L}) \mathrm{Co}_{2}{ }_{2}{ }_{2}\left(\mathrm{MoO}_{3}\left(\mathrm{OCH}_{3}\right)\right)\right]^{+}$cation in crystals of $11 \cdot 6 \mathrm{CH}_{3} \mathrm{OH}$. Thermal ellipsoids are drawn at the $50 \%$ probability level. $H$ atoms are omitted for reasons of clarity.

The structure of $\mathbf{1 0} \cdot \mathrm{CH}_{2} \mathrm{Cl}_{2}$ consists of neutral complexes $\mathbf{1 0}$ and $\mathrm{CH}_{2} \mathrm{Cl}_{2}$ solvate molecules. There are no intermolecular interactions between the components. Figure 7 provides an ORTEP view of the structure of 10. The macrocycle adopts a bowl-shaped conformation, as observed in $\left[(\mathrm{L}) \mathrm{Co}_{2}{ }_{2}(\mathrm{OAc})\right]^{+}[30]$. Each Co atom is coordinated by two $\mathrm{S}$ and three $\mathrm{N}$ atoms from the supporting ligand and an $\mathrm{O}$ atom of a $\mu_{1,3}$-bridging $\mathrm{MoO}_{4}{ }^{2-}$ ion in a severely distorted octahedral fashion. The distortions from the ideal octahedral geometry are manifested in the cis and trans L-Co-L bond angles, which deviate by as much as $24.9^{\circ}$. from their ideal values. The Co-metal ligand bond lengths in $\mathbf{1 0}$ are very similar to those in 9, indicative of a high-spin configuration for the $\mathrm{Co}^{2+}$ ions [90]. The $\mathrm{MoO}_{4}^{2-}$ unit is slightly tilted out of the $\mathrm{Co}_{2} \mathrm{O}_{2}$ plane, with the oxo atom $\mathrm{O}(3)$ pointing in the direction of one benzene ring [distance $\mathrm{O}(3) \cdots \operatorname{centroid}$ of phenyl ring = $3.612 \AA]$. The coordination about Mo is not perfectly tetrahedral. The mean $\mathrm{Mo}=\mathrm{O}[1.712(7) \AA]$ and Mo-O [1.761(6) $\AA$ ] bond lengths differ by ca. $0.05 \AA$, and the O-Mo-O bond angles range from 106.3(3) to 111.5(3) ${ }^{\circ}$. Similar values have been observed for other molybdato-bridged complexes[115] and for the oxo-alkoxo compounds $\mathrm{MoO}_{2}\left(\mathrm{OSiPh}_{3}\right)_{2}$ [104] and $\mathrm{MoO}_{2}\left(\mathrm{O}-2,6-t-\mathrm{Bu}_{2} \mathrm{C}_{6} \mathrm{H}_{2}\right)_{2}$ [105]. It is also worth mentioning that the Co-O distances in $\mathbf{1 0}$ [mean 1.988(6) $\AA$ ] are shorter than those in $\mathbf{1 1}$ [2.027(4) $\AA$ ], an effect that may be traced to stronger electrostatic coligand-metal interactions in $\mathbf{1 0}$.

The crystal structure determination of $\mathbf{1 1} \cdot 6 \mathrm{MeOH}$ unambiguously confirmed the presence of a $\eta^{2}$ - coordinated monomethyl orthomolybdate situated in the pocket of the $\left[(\mathrm{L}) \mathrm{Co}_{2}{ }_{2}\right]^{2+}$ fragment (Figure 9). Further components are a centrosymmetric $\left[\mathrm{Mo}_{4} \mathrm{O}_{10}\left(\mathrm{OCH}_{3}\right)_{6}\right]^{2-}$ counterion and $\mathrm{MeOH}$ solvate molecules. Note that the asymmetric unit contains only half of the atoms of the formula unit. The three independent $\mathrm{MeOH}$ molecules are $\mathrm{H}$-bonded to each other $(\mathrm{O} \cdots \mathrm{O})$ 2.81-2.87 $\AA$ ). One of them is also $\mathrm{H}$-bonded to the polymolybdate ion, but there are no $\mathrm{H}$ bonds with the $\mathrm{MoO}_{3}(\mathrm{OMe})^{-}$ unit. The tilting of the latter toward the $t$-Bu group of the supporting ligand is indicative of an intramolecular Van der Waals interaction $[\mathrm{H}(39 \mathrm{a}) \cdots \mathrm{H}(36 \mathrm{~b}))$ ) $2.313 \AA]$. 
The Mo-O distance to the methoxide ligand $[1.852(5) \AA]$ is significantly longer than the Mo=O distance [1.685- (5) $\AA]$ to the terminal oxo function. The Mo-O distances to the bridging oxides (mean value $1.734 \AA$ ) lie between these two extreme values. This is in contrast to the free $\mathrm{MoO}_{3}\left(\mathrm{OSiCPh}_{3}\right)_{3}{ }^{-}$ion for which one long, one intermediate, and two short Mo-O distances have been reported [106]. The bonding situation in the $\mathrm{MoO}_{3}(\mathrm{OMe})^{-}$ion may be described by the resonance structure depicted below, where bond orders of 2, 1.5, and 1 have been assigned to the individual M-O bonds.<smiles>CO[W](=O)(=O)O</smiles>

It can be seen from Figure 9 that the centrosymmetric $\left[\mathrm{Mo}_{4} \mathrm{O}_{10}(\mathrm{OMe})_{6}\right]^{2-}$ counterion in 11 (Figure 8) is isostructural with that in $\left(\mathrm{MePPh}_{3}\right)_{2}\left[\mathrm{Mo}_{4} \mathrm{O}_{10}\left(\mathrm{OCH}_{3}\right)_{6}\right]$ [97]. There are no unusual features as far as bond lengths and angles are concerned. The average Mo- $(\mu-\mathrm{O})$ [1.923(4) $\AA], \mathrm{Mo}^{-\mathrm{OCH}_{3}}$ [1.919(4) $\left.\AA\right], \mathrm{Mo}-\left(\mu-\mathrm{OCH}_{3}\right)$ [2.135(4) $\left.\AA\right]$, Mo- $\left(\mu_{3}-\mathrm{OCH}_{3}\right)[2.287(4) \AA]$, and $\mathrm{Mo}_{\mathrm{t}} \mathrm{O}_{\mathrm{t}}[1.692(4) \AA]$ bond lengths are similar to the values of the compound above [100].

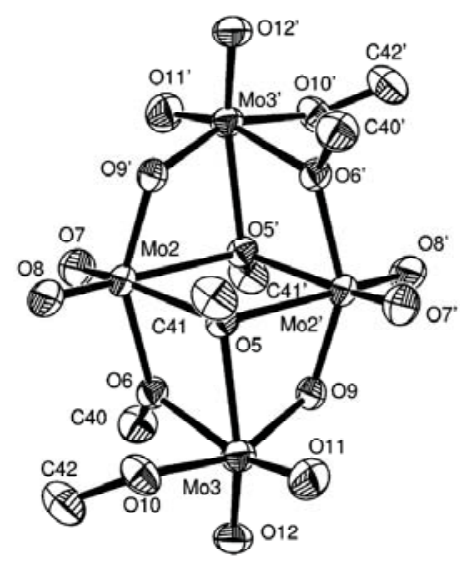

Fig. 9. Structure of the $\left[\mathrm{Mo}_{4} \mathrm{O}_{10}\left(\mathrm{OCH}_{3}\right)_{6}\right]^{2-}$ anion in crystals of $11 \cdot 6 \mathrm{CH}_{3} \mathrm{OH}$. Thermal ellipsoids are drawn at the $50 \%$ probability level. $\mathrm{H}$ atoms are omitted for reasons of clarity.

In summary, we have been able to trap a monomethyl orthomolybdate in the binding pocket of the $\left[(\mathrm{L}) \mathrm{Co}_{2}\right]^{2+}$ fragment. Work in progress is directed toward the synthesis of other ortho esters of the transition metals by taking advantage of the steric protection offered by the supporting ligand. These compounds may also exhibit novel reactivity features that are not seen for the free oxoanions.

\section{Conclusions}

The main findings of these investigations can be summarized as follows: a) It was prepared the first stable dinuclear nickel(II) borohydrido-bridged complex of a macrodinucleating hexaaza-dithiophenolate ligand $\left(\mathrm{L}^{2-}\right)$; b) the steric protection-offered by the supporting ligand $\mathrm{L}^{2-}$ allows for the preparation and isolation of stable hydrosulfide complexes of labile transition metal ions; c) the $\left[(\mathrm{L}) \mathrm{Ni}_{2}\left(\mu-\mathrm{BH}_{4}\right)\right]^{+}$complex reacts rapidly with elemental sulphur and represents a versatile starting material for $\left[(\mathrm{L}) \mathrm{Ni}_{2}(\mu-\mathrm{SH})\right]^{+}$and polysulfide complexes such as $\left.\left[\left\{(\mathrm{L}) \mathrm{Ni}_{2}\right\}_{2}\left(\mu-\mathrm{S}_{6}\right)\right]^{2+} ; \mathrm{d}\right)$ it was demonstrate that the parent $\mathrm{MoO}_{3}\left(\mathrm{OCH}_{3}\right)^{-}$complex can be stabilized by the steric protection of the supporting ligand $\mathrm{L}^{2-}$ in the dinuclear cobalt complex $\left[(\mathrm{L}) \mathrm{Co}_{2}{ }_{2}\right]^{2+}$. Work in progress in this area directed toward the synthesis of new macrocyclic complexes with more deeper binding cavities.

\section{Acknowledgements}

The author is thankful for Prof. B.Kersting (University of Leipzig, Germany) for providing facilities of work in his research group and the German DAAD for financial support.

\section{References}

[1]. Canary, J. W.; Gibb, B. C. Prog. Inorg. Chem. 1997, 45, 1-83. 
[2]. Wieser, C.; Dieleman, C. B.; Matt, D. Coord. Chem. Rev. 1997, 165, 93-161.

[3]. Poorters, L.; Armspach, D.; Matt, D.; Toupet, L.; Jones, P. G. Angew.Chem. 2007, 119, 2717-2719; Angew. Chem., Int. Ed. 2007, 46, 2663-2665.

[4]. Hammes, B. S.; Ramos-Maldonado, D.; Yap, G. P. A.; Liable-Sands, L.; Rheingold, A. L.; Young, V. G., Jr.; Borovik, A. S Inorg. Chem. 1997, 36, 3210-3211.

[5]. Rohde, J.-U.; In, J.-H.; Lee, M. H.; Brennessel, W. W.; Bukowski, M. R.; Stubna, A.; Munck, E.; Nam, W.; Que, L, Jr. Science 2003, 299, 1037-1039.

[6]. Reetz, M. T.; Waldvogel, S. R. Angew. Chem. 1997, 109, 870-873; Angew. Chem., Int. Ed. Engl. 1997, 36, 865867.

[7]. Ooi, T.; Kondo, Y.; Maruoka, K. Angew. Chem. 1998, 110, 3213- 3215; Angew. Chem. Int. Ed. 1998, 37, 30393041.

[8]. Yoshizawa, M.; Takeyama, Y.; Kusukawa, T.; Fujita, M. Angew. Chem. 2002, 114, 1403-1405; Angew. Chem., Int. Ed. 2002, 41, 1347-1349.

[9]. Engeldinger, E.; Armspach, D.; Matt, D. Angew. Chem. 2001, 113, 2594-2597; Angew. Chem. Int Ed. 2001, 40, 2526-2529.

[10]. Slagt, V. F.; Reek, J. N. H.; Kramer, P. C. J.; van Leeuwen, P. W. N. M. Angew. Chem. 2001, 113, 4401- 4404; Angew. Chem., Int. Ed. 2001, 40, 4271-4274.

[11]. Yandulov, D. V.; Schrock, R. R. Science 2003, 301, 76-83.

[12]. Rondelez, Y.; Bertho, G.; Reinaud, O. Angew. Chem. 2002, 114, 1086-1088; Angew. Chem.Int. Ed. 2002, 41, 1044-1046.

[13]. Cameron, B. R.; Loeb, S. J.; Yap, G. P. A. Inorg. Chem. 1997, 36, 5498-5504.

[14]. Kitayima, N.; Tolman, W. B. Prog. Inorg. Chem. 1995, 43, 419-531.

[15]. Trofimenko, S. Scorpionates: The Coordination Chemistry of Polypyrazolylborate Ligands; Imperial College Press: London U.K., 1999.

[16]. MacBeth, C. E.; Golombek, A. P.; Young, V. G., Jr.; Yang, C.; Kuczera, K.; Hendrich, M.P.; Borovik, A. S. Science 2000, 289, 938-941.

[17]. Cho, J.; Yap, G. P. A.; Riordan, C. G. Inorg. Chem. 2007, 46, 11308-11315.

[18]. Desrochers, P. J.; Cutts, R. W.; Rice, P. K.; Golden, M. L.; Graham, J. B.; Barclay, T. M.; Cordes, A. W. Inorg. Chem. 1999, 38, 5690-5694.

[19]. Herold, S.; Lippard, S. J. J. Am. Chem. Soc. 1997, 119, 145-156. He, C.; Lippard, S. J. J. Am. Chem. Soc. 1998, 120, 105-113.

[20]. Hagadorn, J. R.; Que, L, Jr; Tolman, W. B. J. Am. Chem. Soc. 1998, 120, 13531-13532.

[21]. Du Bois, J.; Mizoguchi, T. J.; Lippard, S. J. Coord. Chem. Rev. 2000, 200-202, 443-485.

[22]. Marr, A. C.; Spencer, D. J. E.; Schroder, M. Coord. Chem. Rev. 2001, 219-221, 1055-1074.

[23]. Brooker, S. Coord. Chem. Rev. 2001, 222, 33-56.

[24]. Lozan, V.; Loose, C; Kortusb, J; Kersting, B.Coord. Chem. Rev. 2009, 253, 2244-2260.

[25]. Lozan, V.; Kersting, B. Inorg. Chem. 47 (2008) 5386.

[26]. Kersting, B.; Steinfeld, G. Chem. Commun. 2001, 1376-1377.

[27]. Klingele, M. H.; Steinfeld, G.; Kersting, B. Z. Naturforsch. 2001, 56b, 901-907.

[28]. Hausmann, J.; Klingele, M. H.; Lozan, V.; Steinfeld, G.; Siebert, D.; Journaux, Y.; Girerd, J.-J.; Kersting, B. Chem.Eur. J. 2004, 10, 1716-1728.

[29]. Kersting, B. Angew. Chem. 2001, 113, 4109-4112; Angew. Chem., Int. Ed. 2001, 40, 3987-3990.

[30]. Kersting, B.; Steinfeld, G. Inorg. Chem. 2002, 41, 1140-1150.

[31]. Steinfeld, G.; Lozan, V.; Kersting, B. Angew. Chem. 2003, 115, 2363-2365; Angew. Chem., Int. Ed. 2003, 42, 2261-2263.

[32]. Lozan, V.; Buchholz, A.; Plass, W.; Kersting, B. Chem. Eur. J. 2007, 13, 7305-7316.

[33]. Klingele, J.; Klingele, M. H.; Baars, O.; Lozan, V.; Buchholz, A.; Leibeling, G.; Plass, W.; Meyer, F.; Kersting, B. Eur. J. Inorg. Chem. 2007, 5277-5285.

[34]. Pierpont, C.G.; Hendrickson, D.N.; Duggan, D.M.; Wagner, F.; Barefield, E.K. Inorg. Chem. $1975,14,604$.

[35]. Chaudhuri, P.; Guttmann, M.; Ventur, D.; Wieghardt, K.; Nuber, B.; Weiss, J. J. Chem. Soc., Chem. Commun. 1985, 1618.

[36]. Ribas, J.; Escuer, A.; Monfort, M.; Vicente, R.; Cortes, R.; Lezama, L.; Rojo, T. Coord. Chem. Rev. 1999, 193-195, 1027.

[37]. Hollemann, A.F.; Wiberg, E. Lehrbuch der Anorganischen Chemie, Walter de Gruyter, Berlin, 1985, Vol. 91 , (100 ed, p. 557). 
[38]. Sellmann, D.; Kunstmann, H.; Knoch, F.; Moll, M. Inorg. Chem. 1988, 27, 4183.

[39]. Sellmann, D.; Soglowek, W.; Knoch, F.; Moll, M. Angew. Chem. 1989, 101, 1244; Angew. Chem., Int. Ed. Engl. 1989, 28, 1271.

[40]. Henderson, R.A.; Leigh, G.J.; Pickett, C.J. Adv. Inorg. Chem. Radiochem. 1983, 27, 197.

[41]. Sutton, D. Chem. Rev. 1993, 93, 995.

[42]. Sellmann, D.; Engl, K.; Heinemann, F.W.; Sieler, J. Eur. J. Inorg. Chem. 2000, 1079.

[43]. Matsumoto, K.; Koyama, T.; Koide, Y. J. Am. Chem. Soc. 1999, 121, 10913.

[44]. Matsukawa, S.; Kuwata, S.; Ishii, Y.; Hidai, M. J.Chem. Soc., Dalton Trans. 2002, 2737.

[45]. Blum, L.; Williams, I.D.; Schrock, R.R. J. Am. Chem. Soc. 1984, 106, 8316.

[46]. Murray, R.C.; Schrock, R.R. J. Am. Chem Soc. 1985, 107, 4557.

[47]. Lozan, V.; Kersting, B. Eur. J. Inorg. Chem. 2007, 1436-1443.

[48]. Evans, D.J.; Pickett, C.J. Chem. Soc. Rev., 2003, 32, 268.

[49]. (a) Marr, A.C.; Spencer D.J.E.; Schroder, M. Coord. Chem. Rev., 2001, 219-221, 1055; (b) Brooker, S. Coord. Chem. Rev., 2001, 222, 33-56.

[50]. Grapperhaus, C.A.; Darensbourg, M.Y. Acc. Chem. Res., 1998, 31, 451.

[51]. Lai, C.-H.; Reibenspies, J.H.; Darensbourg, M.Y. Angew. Chem., Int. Ed. Engl., 1996, 35, 2390.

[52]. Davies, S.C.; Evans, D.J.; Hughes, D.L.; Longhurst, S.; Sanders, J.R. Chem. Commun., 1999, 1935.

[53]. Sellmann, D.; Geipel, F.; Lauderbach, F.; Heinemann, F.W. Angew. Chem., Int. Ed., 2002, 41, 632.

[54]. Gloaguen, F.; Lawrence, J.D.; Rauchfuss, T.B. J. Am. Chem. Soc., 2002, 124, 726.

[55]. Amoroso, A.J.; Chung, S.S.M.; Spencer, D.J.E.; Danks, J.P.; Glenny, M.W.; Blake, A.J.; Cooke, P.A.; Wilson, C.; Schroder, M. Chem. Commun., 2003, 2020.

[56]. Desrochers, P.J.; LeLievre, S.; Johnson, R.J.; Lamb, B.T.; Phelps, A.L.; Cordes, A.W.; Gu, W.; Cramer, S.P. Inorg. Chem., 2003, 42, 7945.

[57]. Curtis, N.F. J. Chem. Soc., 1965, 924.

[58]. Marks T.J.; Kolb, J.R. Chem. Rev., 1977, 77, 263.

[59]. Alvarez, H.M.; Krawiec, M.; Donovan-Merkert, B.T.; Fouzi M.; Rabinovich, D. Inorg. Chem., $2001,40,5736$.

[60]. Kuwata, S.; Hidai, M. Coord. Chem. Rev. 2001, 213, 211-305.

[61]. Huang, S. D.; Lai, C. P.; Barnes, C. L. Angew. Chem. 1997, 109, 1961-1964; Angew. Chem., Int. Ed. Engl. 1997, 36, 1854-1856.

[62]. Howard, W. A.; Parkin, G. Organometallics 1993, 12, 2363-2366.

[63]. Rombach, M.; Vahrenkamp, H. Inorg. Chem. 2001, 40, 6144-6150.

[64]. Zhang, Y.; Zuo, J.-L.; Zhou, H.-C.; Holm, R. H. J. Am. Chem. Soc. 2002, 124, 14292-14293.

[65]. Howard, J. B.; Rees, D. C. Chem. Rev. 1996, 96, 2965-2982.

[66]. Fontecilla-Camps, J. C.; Volbeda, A.; Cavazza, C.; Nicolet, Y. Chem. Rev. 2007, 107, 4273-4303.

[67]. Doukov, T. I.; Iverson, T. M.; Seravalli, J.; Ragsdale, S. W.; Drennan, C. L. Science. 2002, 298, $567-572$.

[68]. Peters, J. W.; Lanzilotta, W. N.; Lemon, B. J.; Seefeldt, L. C. Science 1998, 282, 1853-1858.

[69]. a) Swenson, D.; Baenziger, N. C.; Coucouvanis, D. J. Am. Chem. Soc. 1978, 100, 1932-1934. b) Stavropoulos, P.; Carrie, M.; Muetterties, M. C.; Holm, R. H. J. Am. Chem. Soc. 1990, 112, 5385-5387. c) Wilker, J. J.; Gelasco, A.; Pressler, M. A.; Day, R. O.; Maroney, M. J. J. Am. Chem. Soc. 1991, 113, 6342-6343. d) Marganian, C. A.; Vazir, H.; Baidya, N.; Olmstead, M. M.; Mascharak, P. K. J. Am. Chem.Soc. 1995, 117, 1584-1594.

[70]. 70. a) Liu, X.; Ibrahim, S. K.; Tard, C.; Pickett, C. J. Coord. Chem. Rev. 2005, 249, 1641-1652. b) Bouwman, E.; Reedijk, J. Coord. Chem. Rev. 2005, 249, 1555-1581. c) Mealli, C.; Rauchfuss, T. B. Angew. Chem. 2007, 119, 9100-9102; Angew. Chem. 2007, 46, 8942-8944. d) Eckert, N. A.; Dougherty, W. G.; Yap, G. P. A.; Riordan, C. G. J. Am. Chem. Soc. 2007, 129, 9286-9287.

[71]. Gaffney, T. R.; Ibers, J. A. Inorg. Chem. 1982, 21, 2857-2859.

[72]. Rauchfuss, T. B.; Ruffing, C. J. Organometallics 1982, 1, 400-401.

[73]. Mueting, A. M.; Boyle, P.; Pignolet, L. H. Inorg. Chem. 1984, 23, 44-48.

[74]. Krebs, B.; Bobb, W.; Wellmer, H.-J.; Wiesmann, K. Z. Anorg. Allg.Chem. 1994, 620, 1234-1246.

[75]. Journaux, Y.; Lozan, V.; Hausmann, J.; Kersting, B. Chem. Commun. 2006, 83-84.

[76]. Lalancette, J. M.; Freche, A.; Brindle, J. R.; Laliberte, M. Synthesis 1972, 526-532.

[77]. Banister, A. J.; Barr, D.; Brooker, A. T; Clegg, W.; Cunnington, M. J.; Doyle, M. J.; Drake, S. R.; Gill, W. R.; Manning, K.; Raithby, P. R.; Snaith, R.; Wade, K.; Wright, D. S. J. Chem.Soc., Chem. Commun 1990, 105-106.

[78]. Beck, W.; Danzer, W.; Hoferm, R. Angew. Chem. 1973, 85, 87-88; Angew. Chem., Int. Ed. Engl. 1973, 12, 77-78.

[79]. Janz, G. J.; Coutts, J. W.; Downey, J. R.; Roduner, E. Inorg. Chem. 1976, 15, 1755-1759.

[80]. Lever, A. B. P. Inorganic Electronic Spectroscopy, 2nd edition; Elsevier Science: Amsterdam, 1984.

[81]. Beissel, T.; Glaser, T.; Kesting, F.; Wieghardt, K.; Nuber, B. Inorg. Chem. 1996, 35, 3936-3947. 
[82]. Krebs, B. Angew. Chem. 1983, 95, 113-134; Angew. Chem., Int. Ed. Engl. 1983, 22, 113-134.

[83]. Steiner, T. Angew. Chem. 2002, 114, 50-80; Angew. Chem., Int. Ed. 2002, 41, 48-76.

[84]. Huheey, J.; Keiter, E.; Keiter, R. Anorganische Chemie, 2 Aufl.; de-Gruyter: Berlin, 1995; p. 138.

[85]. Gressenbuch, M.; Kersting, B. Eur. J. Inorg. Chem. 2007, 90-102.

[86]. Franolic, J. D.; Wang, W. Y.; Millar, M. J. Am. Chem. Soc. 1992, 114, 6587-6588.

[87]. Silver, A.; Millar, M. J. Chem. Soc., Chem. Commun 1992, 948-949.

[88]. Pleus, R. J.; Waden, H.; Saak, W.; Haase, D.; Pohl, S. Dalton Trans. 1999, 2601-2610.

[89]. Baidya, N.; Olmstead, M.; Mascharak, P. K. Inorg. Chem. 1991, 30, 929-937.

[90]. Journaux, Y.; Glaser, T.; Steinfeld, G.; Lozan, V.; Kersting, B. Dalton Trans. 2006, 1738-1748.

[91]. Beissel, T.; Birkelbach, F.; Bill, E.; Glaser, T.; Kesting, F.; Krebs, C.; Weyhermuller, T.; Wieghardt, K.; Butzlaff, C.; Trautwein, A. X. J. Am. Chem. Soc. 1996, 118, 12376-12390.

[92]. Kersting, B.; Siebert, D. Inorg. Chem. 1998, 37, 3820-3828.

[93]. Greenwood, N. N.; Earnshaw, A. Chemie der Elemente, 1 Aufl.; VCH: Weinheim, 1988; p. 864.

[94]. a) Schnock, M.; Bottcher, P. Z. Naturforsch. 1995, 50b, 721-724. b) Bacher, A.D.; Muller, U.; Ruhlandt-Senge, K. Z. Naturforsch. 1992, 47b, 1673-1676. c) Muller, A.; Zimmermann, M.; Bogge, H. Angew. Chem.1986, 98, 259-260; Angew.Chem. Int. Ed. Engl. 1985, 25, 273-274. d) Draganjac, M.; Rauchfuss, T. B.Angew. Chem. 1985, 97, 745-760; Angew. Chem., Int. Ed. Engl. 1985, 24, 742-762. e) Furuhashi, T.; Kawano, M.; Koide, Y.; Somazawa, R.; Matsumoto, K. Inorg. Chem. 1999, 38, 109-114.

[95]. Tatsumi, K.; Inoue, Y.; Nakamura, A.; Cramer, R. E.; VanDoorne, W.; Gilje, J. W. Angew. Chem. 1990, 102, 455-457; Angew. Chem.,Int. Ed. Engl. 1990, 29, 422-425. Tatsumi, K.; Kawaguchi, H.; Inoue, K.; Tani, K.; Cramer, R. E. Inorg. Chem. 1993, 32, 4317-4323.

[96]. McCarron, E. M.; Staley, R. H.; Sleight, A. W. Inorg. Chem. 1984, 23, 1043-1045.

[97]. Liu, S.; Shaikh, S. N.; Zubieta, J. Inorg. Chem. 1987, 26, 4303- 4305.

[98]. McCarron, E. M.; Harlow, R. L. J. Am. Chem. Soc. 1983, 105, 6179-6181.

[99]. Liu, S.; Shaikh, S. N.; Zubieta, J. Inorg. Chem. 1989, 28, 723-732.

[100]. Kang, H.; Liu, S.; Shaikh, S. N.; Nicholson, T.; Zubieta, J. Inorg.Chem. 1989, 28, 920-933.

[101]. Piarulli, U.; Williams, D. N.; Floriani, C.; Gervasio, G.; Viterbo, D. J. Chem. Soc., Dalton Trans. 1995 , 3329-3334.

[102]. Kim, G. S.; Huffman, D.; DeKock, C. W. Inorg. Chem. 1989, 28, 1279-1283.

[103]. Chisholm, M. H.; Folting, K.; Huffman, J. C.; Kirkpatrick, C. C. Inorg. Chem. 1984, 23, 1021-1037.

[104]. Huang, M.; DeKock, C. W. Inorg. Chem. 1993, 32, 2287-2291.

[105]. Hanna, T. A.; Incarvito, C. D.; Rheingold, A. L. Inorg. Chem. 2000, 39, 630-631.

[106]. Klemperer, W. G.; Mainz, V. V.; Shum, W.; Wang, R. C. Inorg. Chem. 1985, 24, 1968-1970.

[107]. Lubben, T. V.; Wolczanski, P. T.; Van Duyne, G. D. Organometallics 1984, 3, 977- 983.

[108]. Hvoslef, J.; Hope, H.; Murray, B. D.; Power, P. P. Chem. Commun.1983, 1438-1439.

[109]. McKee, V.; Nelson, J.; Town, R. M. Chem. Soc. Rev. 2003, 32, 309-325.

[110]. Brauer, G. Handbuch der Praparativen Anorganischen Chemie, 3rd ) ed.; Ferdinand Enke Verlag: Stuttgart, Germany, 1981; p 1544.

[111]. Clegg, W.; Errington, R. J.; Fraser, K. A.; Richards, D. G. J.Chem. Soc., Chem. Commun. 1993, $1105-1107$.

[112]. Fuchs, J. Z. Naturforsch. 1973, 28b, 389-404.

[113]. Thiele, A.; Fuchs, J. Z. Naturforsch. 1979, 34b, 145-154.

[114]. Coomber, R.; Griffith, W. P. J. Chem. Soc. A 1968, 1128-1131.

[115]. Ghiladi, M.; McKenzie, C. J.; Meier, A.; Powell, A. K.; Ulstrup, J.; Wocadlo, S. J.Chem.Soc., Dalton Trans. 1997, 4011-4018. 